\title{
Children's Rights in China: Protection through Criminal Law
}

Jiang*

Beijing Normal University, College for Criminal Law Science, 100875, P.R. China

\section{Introduction}

Protection on Children's Rights is not only in line with the basic spirit of the Universal Declaration of Human Rights and the relevant international human right treaties, but also involved with the priority area of the Program for The Development of Chinese Children (20112020). Thus, it helps to safeguard the rights of juvenile and strengthen criminal law protection of their rights and interests. In consideration of the weak position of juvenile and the criminal law valve of protecting their rights and interests, this paper will evaluate the latest trends of criminal law protection on juvenile rights and interests from the legislative level in China. It is of great significance to survey the real gap of juvenile protection systems between China and international conventions, and further start the new journey of comprehensive consummation of criminal law protection on juvenile rights and interests.

\section{The Development of Juvenile Protection through Criminal Law}

The Amendment to the Criminal Law of the PRC, adopted at the $19^{\text {th }}$ session of the Standing Committee of the $11^{\text {th }}$ National People's Congress early in this year, has added some general provisions on a lenient punishment for juvenile crime. In the new Amendment, Article 6 excludes juvenile from composition of recidivist, Article 11 provides that probation shall be granted if the said criminal is under the age of 18 and Article 19 exempts them from the duty of reporting their criminal record, all of which are the important contents of juvenile protection systems. This further promotes the connotation development and extension expansion of juvenile protection systems in our country, and impels the general provisions of criminal law to gradually increase the scope and the strength of protection on juvenile, in order to play its full role for human rights protection and reduction of recommitment.

Specifically, Article 65 of the Criminal Law of the PRC has been revised by Article 6 of the new Amendment as, "If a criminal who is sentenced to fixed-term imprisonment or heavier punishments commits another crime punishable by fixed-term imprisonment or heavier punishments within five years after serving his/her sentence or receiving a pardon, he/she is a recidivist and shall be subject to a heavier punishment, with the exception of negligent crimes and crimes committed by a criminal under the age of 18." That is to say, based on the original provisions about recidivism, a person under the age of 18 shall not fell into the category of recidivism. In essence, those who committed the crime under the age of 18 , namely, juvenile shall not constitute a recidivist. Furthermore, Article 11 of the new Amendment also provides that "probation may be granted to a criminal who is sentenced to criminal detention or fixed-term imprisonment of less than three years" and shall be granted if the said criminal under the age of 18 . This means in the cases of juvenile crime, that probation must be granted to juvenile delinquents, only if satisfying the conditions of its application, namely, the effectiveness of probation should be reinforced and not previously "may be granted". Concerning the above two revisions, the new amendment focuses on penalty discretion, aiming to protect juvenile for the better, improve their human rights situation and maintain social harmony and stability. Due to the particularity and limitation of their mental, physical, identifying and control abilities, even if juvenile repeat committing the offense and meet the general conditions of recidivist, their subjective viciousness and personal danger are less than those of adult offenders. Therefore, an aggravated punishment or same treatment, imposed on juvenile offenders as that on adult ones, will be contrary to the basic principle of lenient punishment required for juvenile crime in Chinese criminal law. Accordingly, this will lead to more difficulties to realizing the real purpose of imposing punishment on juvenile offenders and ultimate goal of protecting their legal rights and interests.

In addition, Article 19 of the Amendment VIII newly added the second paragraph to Article 100 of the Criminal Law of the PRC as its Article 100. This means that those "below the age of 18 at the time of committing crimes and sentenced to a fixed-term imprisonment of less than five years", "shall be exempted from the reporting obligation prescribed in the preceding paragraph" of Article 100. Since the preceding paragraph provides for the obligation of a person who was given a criminal punishment by law, to truthfully report it when joining the army or getting a job, the modified Article 100 aims at exempting part of juvenile offenders' reporting obligation. Such offenders with this exemption, are only limited to the category of "those sentenced to a fixed-term imprisonment of not more than five years". This partly exempted obligation not only contributes to educating and transforming juvenile offenders to make them successfully back to society, but also can prevent them from aggravating pessimistic emotions and even increasing difficulties in returning society, by reducing the possibility of such juvenile encountering social discrimination. But different from the system of destroying juvenile's criminal record, after all, exemption of the reporting obligation cannot eliminate the juvenile offenders' criminal label with them for life because of its reform not thorough enough. Even so, as the latest criminal legislation in our country, the Amendment VIII has basically reflected the current development trend of criminal law protection on juvenile, involved in which all provisions concerning punishment for juvenile crime, would be of great significant to further promoting lenient systems on this special group of persons and upgrading the level of human rights protection on them.

\section{A Comparison between the Latest Domestic Legislation and International Convention Standards Concerned}

With approval and implementation of the Convention on the Rights of the Child, the international community pays more and more attention on the largest interests' protection of juvenile by criminal law. In comparison with international convention standards, the relevant specifications in the latest domestic legislation are more decentralized

*Corresponding author: Jiang, Beijing Normal University, College for Criminal Law Science, 100875, P.R. China, Tel: 01058802774; E-mail: na.jiang@bnu.edu.cn

Received April 23, 2014; Accepted September 25, 2014; Published September 30, 2014

Citation: Jiang (2014) Children's Rights in China: Protection through Criminal Law. Intel Prop Rights 2: 128. doi:10.4172/2375-4516.1000128

Copyright: $\odot 2014$ Jiang. This is an open-access article distributed under the terms of the Creative Commons Attribution License, which permits unrestricted use, distribution, and reproduction in any medium, provided the original author and source are credited. 
and deficient, which renders an inadequate and ineffective protection on the relevant rights and interests. At present, the remaining problems and deficiencies can be demonstrated mainly from the following aspects:

\section{The limited scope and insufficient strength of protection}

Juvenile protection system in the latest domestic legislation mainly limited to the scope of lenient punishment and penalty discretion, instead of relating to the relevant aim of legislation, criminal policy, punishment kinds or punishment elimination, etc. Even if on the penalty discretion, it only deals with an exclusion of constituting recidivist and probation that shall be applied in contents, and not such lenient systems as commutation, parole, surrendering or rendering meritorious service on juvenile. Even worse, there is no broadening of the conditions for applying discretion systems, such as probation, commutation and parole, to juvenile as a special group of persons. Obviously, it is disadvantageous to fully or adequately protecting the lawful rights and interests of juvenile offenders and it goes against the basic spirit of ensuring the maximum benefit of juvenile.

Insufficient protection is also the important factor that influences the level of protecting juvenile's rights and interests, which reasons from the aspect of lenient discretion of penalty. Although there are new terms that probation shall be granted to juvenile in the general provisions of the current criminal law, this does not relate to the issue of whether the necessary conditions of applying probation to juvenile can lower than the applying standards of general adult offenders. In the aspect of eliminating criminal punishment, a relatively perfect system on exemption reporting criminal record has neither been built up in the Chinese criminal law code, nor the system of destroying criminal record for juvenile as a vulnerable group of persons. Thus, this kind of system is rather limited in its protection force, which would certainly weaken its effect of education and reform on juvenile and make against a comprehensive and adequate protection on the rights and interests of juvenile offenders.

\section{Improper approach and unsystematic system for protecting juvenile}

At present, the protection way that our country has adopted is traditional and dispersive legislation. It has both advantages of simple operation in technology and such disadvantages as small capacity, dispersive distribution and unsystematic formation. However, as our country continues strengthening protection on the rights and interests of juvenile by criminal law, both addition of the relevant provisions and expansion of systems have become the necessary trend of human rights developments. The dispersive legislative mode cannot satisfy the increasingly objective demand of protecting juvenile' rights and interests any more. Its protection means and system defects also come up against some questions and criticism. First, the dispersive legislation is of relative small capacity, and the way of protecting juvenile is not proper. The shortage of important rights and interests concerned in criminal law protection, certainly will go against fulfilling human right obligations regulated in international conventions and would be difficult to realize a comprehensive protection on juvenile's rights and interests. Second, the dispersive mode of legislation is excessively scattered and unsystematic, with an inappropriate way of protection. The means of dispersive protection on juvenile offenders appear to be contrary to the international trend of reforming juvenile justice and lead to more difficulties to implementation of the relevant criminal policy in China. 